Accepted version 09/01/2016, in Marine Policy, doi: 10.1016/j.marpol.2016.01.010

\title{
Ocean Governance and Maritime Security in a Placeful Environment: The Case of the European Union
}

\author{
By Basil Germond (University of Lancaster) and Celine Germond-Duret (Liverpool John Moores \\ University)
}

\begin{abstract}
Adopting a critical geopolitics approach that accounts for the mutually reinforcing link between geo-informed narratives and power projection practices, this article proposes that ocean governance and maritime security have translated into states' and regional organisations' increasing control over maritime spaces. This leads to a certain territorialisation of the sea, not so much from a sovereignty and jurisdictional perspective but from a functional and normative perspective. The article starts by discussing the ways oceans have been represented and shows that they are far from a placeless void, both in practice and in discourse. The article then frames the analysis of ocean governance and maritime security within critical geopolitics, and elaborates on the case of the European Union's narrative and practice. It concludes on the mutually reinforcing link between discourse and practice in the field of ocean governance and maritime security in general, and on the consequences in terms of power projection for the EU in particular. Scholars working on ocean governance and maritime security are encouraged to challenge the traditional view that oceans are placeless.
\end{abstract}

KEYWORDS: Ocean governance, Maritime security, Critical geopolitics, European Union, Placelessness

\section{Introduction}

The recent narrative and practice of ocean governance and maritime security have translated into states' and regional organisations' increasing control over maritime spaces. This has led to a certain territorialisation of the sea, not so much from a sovereignty and jurisdictional perspective but from a functional and normative perspective. This article aims at discussing the extent to which oceans are placeless or placeful and the significance in terms of ocean governance, via the compared analysis of both the narrative and the practice of the European Union (EU).

The article starts by discussing the ways oceans have been represented and shows that they are far from a placeless void, both in practice and in discourse. The next section then frames the analysis of ocean governance and maritime security within critical geopolitics, which accounts for the mutually reinforcing link between narrative and practice applied to the geographical space. The analytical framework is then applied to the case of the EU, by deconstructing its ocean governance and maritime security narrative and practice at the security, economic and environmental levels. The findings show that while the practice indicates that the sea is actually placeful and the narrative indeed justifies control, the narrative still consists in a mix of placeful and placeless representations. 


\section{Representing the Oceans: Void or Place?}

The sea has traditionally been represented as an unknown, hazardous, unpredictable, inhospitable, infinite, unregulated, lawless and, ultimately, uninhabitable milieu. Thus, in binary terms, the sea is constructed as the land's other. The fluid/liquid nature of water is opposed to the solid/static nature of the land. As stated by Anderson and Peter, "the sea's physical constitution renders it as intrinsically 'other'; it is a fluid world rather than a solid one. Our normative experiences of the world centre on engagements on solid ground; rather than in liquid sea" (2014: 5). In other words, the sea has traditionally been considered and represented as a placeless void, an 'empty' space outside of human and social experience. Sailors, fishermen and tourists experience the sea through the ship, which is the place of human experience, 'floating' on the blue void. This explains why human geography as an academic discipline has not been much interested in the sea, to the point that it has been defined as a "landlocked field" (Lambert et al. 2006: 480). The ocean was "best left to the natural sciences" (Gillis, 2011: 17). And the maritime space has thus traditionally been analysed as if placeless. For example, in their study of the strategic role of ports for cruise business Gui and Russo (2011) postulates that "most part of [tourists'] experience happens in a placeless environment" (129). Their argument is based on the growing marginalisation of destination ports compared to the ships themselves, which are becoming the true destination place for tourists embarking on a cruise. The sea itself is not even considered as a likely place. In another example, Bush et al.'s study on fishing and sustainability (2015) makes the postulate that oceans are placeless. They refer to oceans' relative inaccessibility and the abstracted ways in which one experiences them. They consider the United Nations Convention on the Law of the Sea (UNCLOS)'s attempts to create territories in the marine environment as abstract and placeless as well (resulting in "highly stylised, homogenising and placeless geography of the marine environment", 2-3). This is debatable, as UNCLOS could on the contrary illustrate a move towards placefulness, since it extends to the sea the political interactions and political/social realities found on land (such as borders, jurisdictions, etc.).

In his seminal book the Social Construction of the Ocean (2001), Steinberg deconstructs the narrative consisting in representing "ocean space" as a great void, which he considers "an attempt to annihilate the ocean" (166) . According to him this representation has served the post-modern capitalism's interests by reducing the seas to an empty void through which capital and goods shall transit quickly and freely. The sea is indeed constructed as a "friction free surface across which capital can move without hindrance" (165). Gillis (2012) links oceans' placelessness to their timelessness, since human geographers' disinterest for the sea mirrors in historians' traditional belief that "time began and ended at the edge of the land" (13), resulting in a lack of interest for the sea as a milieu. Interestingly, traditional naval scholars have mainly represented the sea as a mere lane of communication, which allows commerce to flourish and navies to protect the commerce and to reach any (land) place in the world (naval power projection), also emphasising on the freedom of manoeuvre enjoyed at sea due to its natural characteristics. For Corbett, serving as a means of communication is even "the only positive value which the high seas have for national life" (Corbett, 1911: 93). In sum, the underlying idea that the sea is placeless has been dominant in social science; the sea is an "anonymous" space (Relph, 1976: 143) devoid of social interactions and does not contribute to shaping identity beyond being a mere context for human, social and political interactions.

To consider that the sea is placeless, and especially to consider that the sea does not contribute to identity building and is an anonymous space devoid of any feeling of insideness, is Western-centred and does not take into consideration perceptions by other societies, including several indigenous societies (including some living within the territory of dominant 
Western societies). As stated by Anderson and Peters, who take the example of gift-giving rituals at sea in the Western Pacific, "despite Western culture's willingness to reduce the water world to an empty space, many 'indigenous' cultures refute this essentialism" (2014: 8). Gillis acknowledges the existence of a Pacific and Asiatic vision which differs from the Western one: "for Pacific islanders, the ocean is not a placeless place, but a sea of islands with its own unique geography. For them, history does not begin and end with land, but it is inextricably bound up with the sea itself" (2011: 17). In her study of the Sri Lanka's East coast, Lehman demonstrates the centrality of the ocean in the region's armed conflict and during the 2004 tsunami. She shows how the ocean plays a fundamental role in the lives of the fishing community as a means of livelihood, "rather than through myth or legend" (2013: 492). While the sea is often depicted as being unpredictable (adding to the inhospitable argument playing in favour of its placelessness), the fisherfolks she interviewed seemed on the contrary to find the ocean very reliable. Similarly, in her ethnographic work on the people of Hudson Bay, Tyrrell (2006) shows the extent to which "the sea is important, not only as an economic resource and as a means to travel and movement, but as a place where identity is formed, where memories are created, and where the history of the community lives amongst the rocks, the seaweed and the ever-changing water" (222).

The identity argument is central to most reflections on the concept of place. In a general manner, the identity of fishing communities (who work on the seas and live by the sea) can probably be said to strongly relate to the sea. The sea is also linked to the identity of several other communities, who can feel a 'sense of place', such as professional sailors and, more strikingly, 'boat people'. Brstilo (2013) discussés the case of Filipino sailors and shows that they constitute a "sea-based diaspora"; the sea being a place of "human experience" for them (31). For migrants crossing the Mediterranean, risking their lives, the sea may be both a place of hope (leading to a 'better' life) and despair (facing dangers); a place of life and death, which becomes forcibly linked to their (evolving) identity, or at least to their identity as constructed by others. Indeed, in Western representations (for example in the media treatment of the current refugees/immigration crisis in Europe) migrants are associated with boats and their attempts at crossing the sea; their identity is often reduced to the act of crossing the sea (and dying at sea).

In sum, the sea is far from a void and can definitely be considered as a "social space" (Cusak, 2014) or even as placeful. However, labelling the sea as placeless or placeful is a subjective act, since attributing a sense of place depends on one's values and perception. Placelessness is a relative concept: there is not $a$ sea; the sea is not $a$ place, but there are several seas; the sea is made of various places, which are not experienced in the same way. Thus, some parts of the sea are certainly not experienced as places. In other words, the sea can be placeless in some 'places' and placeful in others; the sea can be placeless for some people and not for others; certain parts of the oceans can be placeless for some actors and individuals, and not for others. It would be wrong to consider oceans as one place, as it would be wrong to consider the land as one place.

This article argues that states' willingness to govern the oceans and control the maritime domain has created various layers of human, social and political interactions related to, and within, the oceans. States represent the embodiment of public power; they are granted with, or claim, the right and responsibility to guide, constrain, monitor, control, and repress human activities at sea. This represents social interactions, which tend to play in favour of the argument that the sea is not placeless. Ocean governance and maritime security go beyond Steinberg's discussion of stewardship of the oceans (2001: 176-180). Stewardship is about resources management. Governance and maritime security is (also) about managing and controlling human activities in the maritime domain. Is it possible to govern something that is not a place? A placeless representation of the ocean may well, in theory, contribute to 
reducing incentives for stewardship, since it induces a lack of identity feeling and thus of care. On the other hand, the placeless narrative may not contradict the stewardship practice, since resource management is ultimately supposed to positively impact on individuals' well-being on land (via economic growth).

In practice, there has been a certain territorialisation of the sea, that is to say that states functionally extend their territory (for example via marine spatial planning) towards the high seas and exert a control over resources but also over human activities as far away from the coast as possible. In the Exclusive Economic Zones (EEZs), which account for about $40 \%$ of the oceans, states have important jurisdictional powers, although mainly limited to economic rights. This seemingly pressing need to control the oceans is also found in the global dominant discourse about the maritime domain, especially in official documents but also in civilian stakeholders' narratives that insist on the need for more control so as to have security and good governance at sea. For example, the European Union's narrative stresses that economic growth cannot be sustained if security does not prevail in the maritime domain, since security is a crucial prerequisite for investments and growth (e.g. Damanaki, 2014). This securitising move follows the more general securitisation trend that has followed the end of the Cold War, i.e. the broadening and deepening of the concept of security beyond military issues and territorial defence and the inclusion of many non-military elements into the definition of security, as well as the propensity to put a 'security' label on various issues (e.g. Buzan et al., 1998).

This article postulates that the sea has definitely become placeful notably because of the current practice of control, governance and territorialisation. The question remains as to whether this has also translated into a new narrative. Has the dominant discourse continued to represent the sea as lawless and placeless so as to justify a practice tending to extend public power's control over the maritime domain? Or has the discourse also evolved towards a representation of the sea as placeful? Ultimately, is the sea a place just like the land, and must it be governed and controlled, just like the land must be?

\section{The Critical Geopolitics of Ocean Governance and Maritime Security}

Critical geopolitics as an academic discipline was born in the 1980s out of scholars' desire to critically discuss the relationship between geography and power while rejecting the tenets of classical geopolitics considered as a theoretical tool at the disposal of the proponents of geopower politics. Geraroíd Ó Tuathail and John Agnew, two pioneering scholars in the field of critical geopolitics, have conceptualized geopolitics "as a discursive practice by which intellectuals of statecraft 'spatialize' international politics in such a way as to represent it as a 'world' characterized by particular types of places, people and dramas" (1992: 192). Indeed, framed within post-structuralism, critical geopolitics is interested in discussing and deconstructing the mutually reinforcing nature of the link between geo-informed series of representations and power, or power projection (including the notion of control). In other words, how do certain geographical representations contribute to the normalisation of certain practices via the construction of certain truths, including on the (geographical) origin of threats and the characteristics of the milieu? Discourse and practice mutually reinforce each other: 'geography is not a natural given but a power-knowledge relationship' (Ó Tuathail, 1996: 10).

Critical geopolitics is thus interested in deconstructing geo-informed binary identities that are framed within the dichotomy between the 'inside' (good, safe, but under threat from the 'outside') and the 'outside' (bad, dangerous, and threatening the 'inside'). The use of such geo-binaries not only reinforces identities along an opposition between the 'us' and the 
'them'; they also normalize the practice consisting in projecting normative and 'hard' power into the 'them' space so as to obtain security within the boundary of the 'us', based on the belief that threats must be tackled as far away from 'home' as possible, which justifies a practice consisting in controlling space far away from home (on binary thinking, see Germond-Duret, forthcoming). Applied to the maritime domain, critical geopolitics, as an approach, reveals useful in exposing the way maritime spaces are constructed in relation to one's own identity and to perceived (or constructed) external threats, and how this contributes to normalizing a practice that consists in projecting power onto, and controlling, the maritime domain beyond one's territorial and jurisdictional waters. As discussed above, such a construction can be framed within a placeless or a placeful representation of the oceans.

The sea is uninhabitable and by nature the maritime domain cannot be occupied; only can it be controlled (or commanded) (Corbett, 1911). Still, the degree of control a state can exert on the sea is relative, limited and subject to change. Controlling sea lanes of communications (SLOCs) has been the core function of naval forces at least since the beginning of the modern era. However, in legal terms, this has not translated into a proper territorialisation of the sea. The maritime domain (with the exception of territorial sea and jurisdictional waters, mainly EEZs) is a space of liberty, where states and non-state actors can operate rather freely, without many legal and police constraints. Even in territorial sea, innocent passage is supposedly authorised, even for military ships under the old Grotian principle of mare liberum. The sea has been conceived as a great common that states and commercial actors should be free to use for travel and transportation. This is what Steinberg calls a "spatial ideology" at the service of the Capital (2001: 165) and Connery the "bourgeois idealization of sea power" (1994: 40). Most critical scholars have, however, failed to go beyond the recognition of a link between this particular construction of the sea and the rise of capitalism to take into account geopolitical and security interests. Glück (2015) demonstrates the link between the representation of the sea as 'empty' and the "production of security space" at sea, that is to say a narrative justifying, and a practice consisting in, power projection into the maritime domain. The strongest states have managed to use seapower to their advantage throughout history. The sea is a wide space that states' naval forces can easily use to reach any destination. Under the international law of the sea, they can operate freely without violating any norms and rules, such as the principles of non-interference in other states' domestic affairs. Thus, states having developed naval power are in a position to project power and forces far away from home.

Whereas the high seas mainly remain an unregulated space when it comes to security (particularly since regulations are hard to enforce), territorial and jurisdictional waters are growingly controlled by state actors. Those littoral and adjacent spaces have extended states' rights and responsibilities, notably in terms of resource management. Controlling the sea, especially in adjacent regions, or what Germond (2010) calls "maritime margins", is a way to extend one's territory beyond one's territorial water, not legally speaking but functionally speaking. Under the banner of ocean governance (including the protection of marine resources) and maritime security (i.e. the struggle against criminal actors operating at or from the sea), states actually extend their control over extra-national spaces.

The rationale for extending states' control over maritime spaces and the narrative justifying such a practice are twofold: 1) States put forward their legal, political and ethical responsibility to govern and secure the oceans, which fits with the liberal notion of protecting and managing the global commons, especially under the banner of regional organisations such as the EU; 2) States also have security interests that require managing the flow of goods and people in adjacent regions, especially the incoming flows, such as illegal immigration, drug, arms and people smuggling, etc. 
Controlling, managing or stewarding the maritime domain is still about controlling SLOCs more than occupying maritime spaces, but the ocean governance and maritime security narrative justifies states' and regional organisations' practice of controlling the maritime domain, which, in practice, can take the form of implementing norms and regulations as well as police and naval operations. In discourses, the ocean is recurrently represented as an ungoverned space (or lawless place) that is prone to the proliferation of threats, especially if criminals are left to operate freely. Marine resources are represented as under threat as well, since they are finite and/or vulnerable. As shown in figure 1, this narrative leads to the justification for ocean governance and maritime security policies so as to monitor and regulate human activities at sea. In practice, this justifies a variety of operations ranging from policing the sea to deterring illegal migrants to counter-piracy to fisheries monitoring (power projection/control). It also justifies the projection of norms and regulations such as fishing quotas, marine environment protection standards, etc. As a result, this engenders a certain territorialisation of the sea in that states control maritime spaces from a functional and normative perspective. This, in turn, tends to turn the sea into a placeful environment, at least in practice if not in rhetoric.

\section{Figure 1: A Critical Geopolitics of Ocean Governance and Maritime Security}

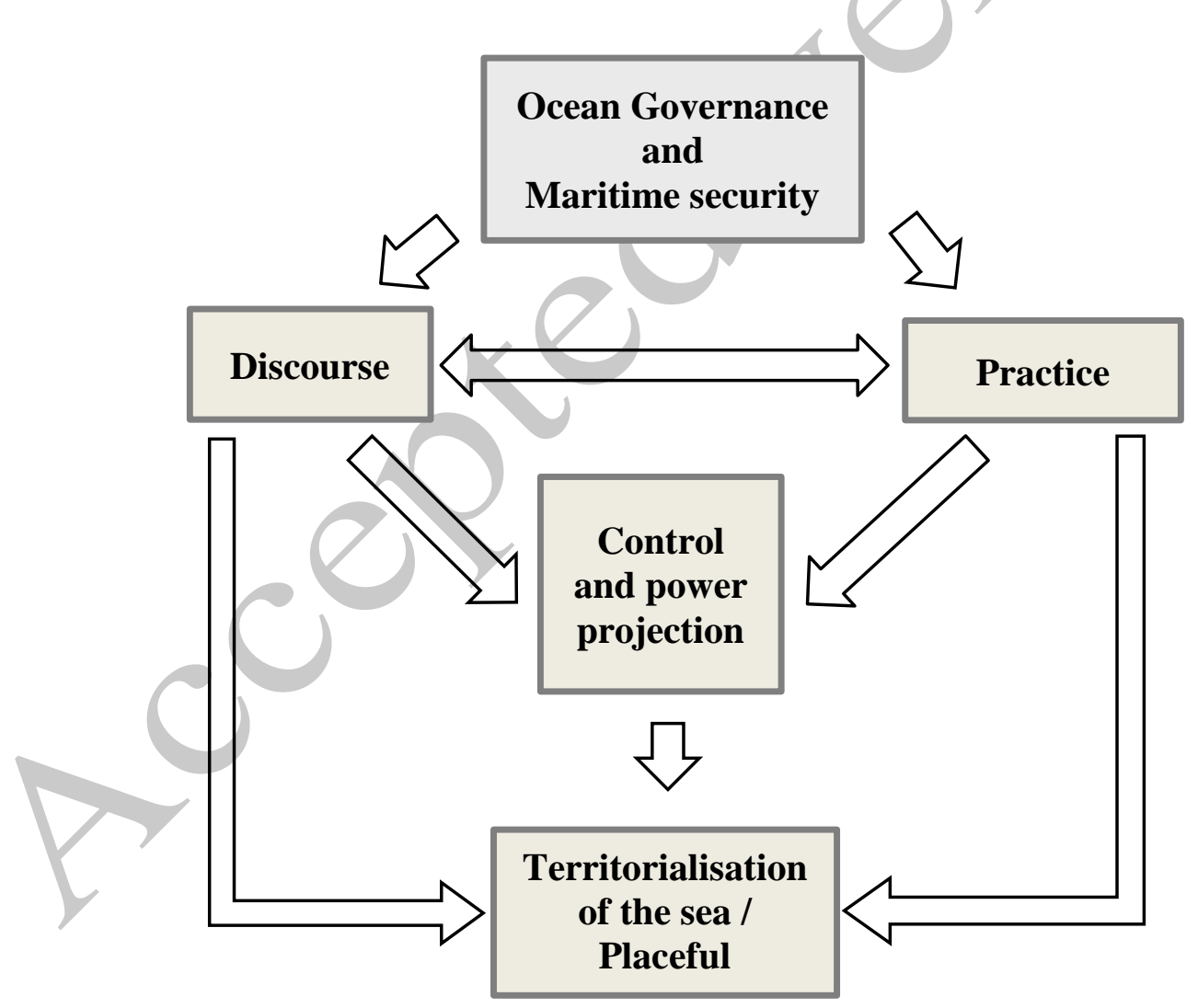




\section{Deconstructing the Maritime Geopolitics of the EU}

In 2003, the European Union launched its first two operations under the rubric of the ESDP (now CSDP) $^{1}$ in the Former Yugoslav Republic of Macedonia and in the Democratic Republic of Congo, and released the European Security Strategy (ESS). It thus became de facto, and to some extent, a security actor with the determination and capabilities to project power beyond its external boundary, albeit in a limited form. Although the Council of the European Union then stressed, on paper, the potential use of naval components during CSDP operations, and although piracy was listed as a potential threat in the ESS, the naval dimension of the EU was purely theoretical and, in practice, just a sweet dream with no commentator even discussing this possibility until 2008 and the (rather unexpected) launch of counter-piracy operation Atalanta at the Horn of Africa. A pioneering study by Germond (2007) acknowledged for the first time the relevance of the naval and maritime dimension of the EU, though, putting the emphasis on the fact that beyond a potential naval dimension of the CSDP the EU was already a security actor at sea in the field of counter-immigration, fisheries protection, and marine environment protection.

The launch of operation Atalanta in December 2008 radically changed the boundary of what has become not only possible but also acceptable for the EU to do at sea; indeed, not only was Atalanta the first ever EU naval operation, it was also the first ever CSDP operation that directly served member states' security interests by directly protecting their maritime trade and the SLOCs to and from the EU (Germond and Smith, 2009). Atalanta is still ongoing (to 2016 at least) making it one of the lengthiest CSDP operations. It was complemented in 2012 by a maritime capacity-building operation (EUCAP Nestor), which, in the spirit of the EU's comprehensive approach to security, aims at fostering local maritime security capabilities so as to reduce the need for external actors to carry out the burden of counter-piracy in the region.

Since the mid-2000s, the EU also started to be more proactive at sea outside the CSDP. In addition to various marine environment protection initiatives, the Commission defined an integrated maritime policy (IMP) in 2007, which aims at integrating horizontally sector-based maritime policies and activities. The IMP has mainly been driven by economic considerations, i.e. the current Blue Growth narrative: "the first goal of [the IMP] is to create optimal conditions for the sustainable use of the oceans and seas, enabling the growth of maritime sectors and coastal regions" (Commission, 2007: 7). However, since the inception of the IMP in 2007, it became clear that without security and stability at sea, economic actors would not be in a position to invest and grow their activities in the maritime sector and domain. This realisation eventually led to the adoption of the EU Maritime Security Strategy (EU MSS) by the Council in June 2014. The EU MSS emphasises the need for the EU to be more proactive at sea in dealing with various sources of insecurity, using both CSDP and nonCSDP instruments, and operating in various functional and geographical areas of interest to the EU. In parallel, 2014 saw the launch of operation Triton (coordinated by the decentralised agency responsible for the management of the EU's external boundary - FRONTEX); Triton is a counter-immigration/search \& rescue operation in central Mediterranean responding to member states' (especially Italy's) request for help to deal with the increasing number of illegal migrants crossing the Mediterranean Sea; FRONTEX coordinates similar operations in other areas, such as operation Poseidon in the Aegean Sea. In June 2015, the Council launched EUNAVFOR-Med (operation Sophia); a naval operation under the rubric of the CSDP that aims at countering human smuggling in the Mediterranean, specifically targeting the perpetrators of human trafficking rather than the migrants per se.

\footnotetext{
${ }^{1}$ ESDP stands for European Security and Defence Policy. Following the 2009 Lisbon Treaty it became the Common Security and Defence Policy (CSDP). For clarity purposes we refer to the CSDP throughout the article.
} 
So far, the literature on the maritime dimension of the European Union has focused on some specific dimensions. In addition to the many studies that have focused on the success and failures of the EU's fisheries and marine environment protection policies, debates have revolved around the Union's involvement in counter-piracy (e.g. Bueger, 2013; 2014; 2015; Germond and Smith, 2009; Riddervold, 2011; 2014), illegal immigration and the role of FRONTEX (e.g. Baldaccini, 2010; Papastavridis, 2010), as well as maritime transport and port security (e.g. Papa, 2013). Only a handful of scholars have discussed the maritime dimension of the EU's geopolitics, focusing on the EU's grand strategy (Rogers, 2009, 2010), maritime security and seapower (Germond, 2010, 2011, 2013, 2015b) and ocean governance (Suárez de Vivero \& Rodríguez Mateos, 2006; 2014). Only Germond (2013) briefly exposed the added value of critical geopolitics to the study of the maritime dimension of the EU. By deconstructing the ocean governance and maritime security narrative and the practice of the $\mathrm{EU}$, the following analysis demonstrates that the naval and maritime dimension of the EU has a strong geopolitical dimension, which can be framed within an understanding of the ocean as placeful.

\subsection{The EU's geopolitical narrative of ocean governance and maritime security}

This sub-section analyses four maritime-related documents released by the Council, the Parliament and the Commission: The directive on the development of a Marine Strategy (EU law, 2008), the regulation on the Integrated Maritime Policy (IMP) (EU law, 2011), the Commission's communication on the Blue Growth (Commission, 2012), and the EU's Maritime Security Strategy (Council, 2014). This choice of texts responds to the need to discuss the security, economic and environmental dimensions of the EU's ocean governance narrative. They are high level documents that have been endorsed by the highest EU bodies and that are meant to shape the conduct of the EU's activities at sea in various capacities and in various functional and geographical areas. In addition to having different aims, these texts are located in different institutional planes, i.e. the Commission, the Council and the Parliament; there is one regulation and one directive which are binding legislative acts, as well as one Commission's communication and one Council's strategy, which are roadmaps setting up priorities and policy objectives, with no mandatory authority or legal effect but with high political value. This combination also reflects the informal division of tasks between the two institutional components of the Union, with the Council acting as the primary decisionmaking organ when it comes to security matters. This allows conducting a comparison between the security, economic and environmental dimensions and between the Council (that is to say the intergovernmental body which is the sum of the member states, which reflects in decisions being often reduced to the smaller common denominator) and the Commission (that is to say the supranational organ that is supposed to work for the common good beyond member states' divergences). 
Table 1: Indicators for coding

\begin{tabular}{|c|c|c|c|}
\hline Variable & Categories & \multicolumn{2}{|c|}{ Indicators } \\
\hline \multirow[t]{2}{*}{$\begin{array}{l}\text { Sea represented as in } \\
\text { need of governance, } \\
\text { control and security }\end{array}$} & A placeful environment & $\begin{array}{l}\text { References to the need to } \\
\text { control human activities at } \\
\text { sea and/or steward marine } \\
\text { resources [ConPlaceful1] }\end{array}$ & $\begin{array}{l}\text { References to the social } \\
\text { character of the sea or its } \\
\text { role in social interactions } \\
\text { [ConPlaceful2] }\end{array}$ \\
\hline & A placeless environment & $\begin{array}{l}\text { Representation of the sea } \\
\text { as lawless, not enough } \\
\text { governed, prone to the } \\
\text { proliferation of criminal } \\
\text { activities [Conplaceless1] }\end{array}$ & $\begin{array}{l}\text { Representation of the sea } \\
\text { as a void, as empty, } \\
\text { devoid of identity } \\
\text { [ConPlaceless2] }\end{array}$ \\
\hline \multirow{2}{*}{$\begin{array}{l}\text { Geopolitical approach } \\
\text { towards maritime } \\
\text { security and ocean } \\
\text { governance }\end{array}$} & $\begin{array}{l}\text { Tacit link between ocean } \\
\text { governance/maritime } \\
\text { security and geopolitics }\end{array}$ & $\begin{array}{l}\text { Geographical definition of } \\
\text { risks, threats and issues } \\
\text { [Tgeopol1] }\end{array}$ & $\begin{array}{l}\text { Recurrent geographical } \\
\text { references throughout } \\
\text { the text [Tgeopol2] }\end{array}$ \\
\hline & $\begin{array}{l}\text { Explicit link between ocean } \\
\text { governance/maritime } \\
\text { security and geopolitics }\end{array}$ & $\begin{array}{l}\text { Reference to the concept } \\
\text { of geopolitics [Egeopol1] }\end{array}$ & $\begin{array}{l}\text { Reference to the } \\
\text { influence of geography } \\
\text { on ocean governance } \\
\text { and maritime security } \\
\text { [Egeopol2] }\end{array}$ \\
\hline \multirow[t]{2}{*}{$\begin{array}{l}\text { Extent to which } \\
\text { geopolitical } \\
\text { considerations inform } \\
\text { policy objectives }\end{array}$} & $\begin{array}{l}\text { Indirect influence of } \\
\text { geographical and or } \\
\text { geopolitical factors on } \\
\text { maritime policy objectives }\end{array}$ & $\begin{array}{l}\text { Reference to the need to } \\
\text { tackle threats and issues } \\
\text { beyond one's boundary } \\
\text { and/or territorial sea }\end{array}$ & $\begin{array}{l}\text { Reference to the need to } \\
\text { govern/control the } \\
\text { 'global' maritime } \\
\text { domain [IgeoInfl2] }\end{array}$ \\
\hline & $\begin{array}{l}\text { Direct influence of } \\
\text { geographical and/or } \\
\text { geopolitical factors on } \\
\text { maritime policy objectives }\end{array}$ & $\begin{array}{l}\text { Direct reference to } \\
\text { geopolitical interests in the } \\
\text { maritime domain } \\
\text { [DgeoInfl1)] }\end{array}$ & $\begin{array}{l}\text { Mention of geographical } \\
\text { locations when referring } \\
\text { to objectives } \\
{[\text { DgeoInfl2)] }}\end{array}$ \\
\hline
\end{tabular}

Building on Germond (2015a: 139), three variables are under scrutiny: 1) 'the extent to which the sea is represented as in need of governance, control and security', for which two categories are defined; a placeful versus a placeless environment, 2) the 'geopolitical approach towards maritime security and ocean governance', for which two categories are defined; a tacit versus an explicit approach, and 3) the 'extent to which geopolitical considerations inform policy objectives', for which two categories are defined; a direct versus indirect influence. The indicators employed for the coding are exposed in Table 1. They are then applied to the analysis of the four above-mentioned texts (with the codes in brackets). The representation of the sea as in need of control is measured by the occurrence of references to the need to control human activities at sea and/or to steward marine resources and by the role played by oceans in social interactions (placeful environment) or, on the contrary, by references to the lawless and empty nature of the maritime domain (placeless environment). The presence of an explicit link between ocean governance/maritime security and geopolitics is measured by the occurrence of unequivocal references to the concept of geopolitics and to the fact that geographical realities influence maritime security and ocean governance. The direct influence of geopolitical factors on maritime policy objectives is measured by the occurrence of unequivocal references to geopolitical interests in the maritime domain and to geographical locations when referring to maritime policy objectives.

The 2008 Marine Strategy, whose overall objective is the protection of the marine environment, is an EU directive, which means that it is legally binding, although member states are free as to the way they implement it. As a legally binding text, the document is 
written in a very diplomatic and legal style. The directive expresses the need to manage human activities at sea that impact on the marine environment and the narrative tends to present ocean governance as the solution to marine pollution problems [ConPlaceful1]. The directive defines relevant "marine waters" as those under the sovereignty and jurisdiction of the member states. This includes wide geographical areas grouped under a variety of marine regions, notably the Baltic Sea, the North-east Atlantic Ocean, the Mediterranean Sea, and the Black Sea (EU law, 2008: article 4.1). The waters around member states' overseas possessions are (with many exceptions) also included (EU law, 2008: preamble 1, article 3.1). The recurrent use of geographical references throughout the text is clear [Tgeopol2]. However, although the document mentions geographical locations when referring to marine environmental protection objectives (such as protecting sea basins) [DgeoInfl2], the direct influence of geographical factors on maritime policy objectives is debatable since these references results from physical geography (marine biology) realities rather than geopolitical (control) objectives. The unbound nature of the sea, "the dynamic nature of marine ecosystems and their natural variability" (preamble 34), and the transboundary effects of marine pollution, are also acknowledged since marine basins are shared including with nonEU members (EU law, 2008: preamble 1, article 2.1):

\footnotetext{
"Since marine regions or subregions are shared both with other Member States and with third countries, Member States should make every effort to ensure close coordination with all Member States and third countries concerned" (EU law, 2008: preamble 13).

"Third countries with waters in the same marine region or subregion as a Member State should be invited to participate in the process laid down in this Directive, thereby facilitating achievement of good environmental status in the marine region or subregion concerned" (EU law, 2008: preamble 20) [Egeopol2, IgeoInfl1].
}

In sum, the link between ocean governance and geography is explicit, but the influence of geography on policy objective remains indirect. That said, the document's general tone leaves no doubt about the fact that good governance shall be projected into maritime spaces within the territorial and jurisdictional waters of the member states and beyond. Given the nature of the sea and of the marine pollution problems, boundaries are tacitly presented as irrelevant for, if not detrimental to, marine environment protection. The EU's and member states' involvement beyond those boundaries thus becomes the 'natural' solution to a 'fluid' problem such as marine pollution [Conplaceless1]. Thus, marine environment protection requires control of human activities in a placeful environment but also stewarding resources in a placeless environment.

The 2011 regulation on the Integrated Maritime Policy draws from the 'Blue Book' released by the Commission in 2007. Although the legally binding regulation offers a clear picture of the officially agreed vision on ocean governance shared by all member states and approved by the Council and the Parliament, it is also important to refer to the Commission's communication, which has informed the regulation, is more detailed, and reflects the view of various European stakeholders that have been extensively consulted. Both documents stress the need to monitor human activities at sea and to project good governance into the maritime domain, or in other words "to foster the development and implementation of integrated governance of maritime and coastal affairs" (EU Law, 2011: article 2) [ConPlaceful1]. This objective is based on the realisation that the seas are central to Europe's "well-being and prosperity", but that "the cumulated effect of all [the human activities affecting the sea leads] to conflicts of use and to the deterioration of the marine environment that everything else depends on". Consequently, "an Integrated Maritime Policy will enhance Europe's capacity to face the challenges of globalisation and competitiveness, climate change, degradation of the 
marine environment, maritime safety and security, and energy security and sustainability" (Commission, 2007: 2) [ConPlaceless1]. Here again, the need to integrate maritime policies at the European level results both from the ungoverned characteristics of the 'empty' sea and from the existence of human interactions at sea.

This ocean governance narrative is tacitly backed by a certain geopolitical narrative that calls for "promoting Europe's leadership in international maritime affairs", with a view of developing "shared responsibility over the seas it shares with its closest neighbours." (Commission, 2007: 13) [Egeopol2]. Third countries are thus "urged to ratify and implement the United Nations Convention on the Law of the Sea" (EU Law, 2011: article 2). Although the two documents do not overemphasise geographical factors, there is nonetheless one important direct mention of the importance of geopolitics: "attention will also be given to the geopolitical implications of climate change. In this context, the Commission will present in 2008 a report on strategic issues relating to the Arctic Ocean." (Commission, 2007: 13) [Egeopol1, DgeoInfl2]. The geographical dimension of ocean governance is also highlighted in that maritime surveillance (of the vast maritime domain) is presented as key to ocean governance success:

\footnotetext{
"The Common Information Sharing Environment for the Union maritime domain which promotes cross-sectoral and cross-border surveillance information exchange interlinking all user communities, in line with the principles of the Integrated Maritime Surveillance so as to reinforce the safe, secure and sustainable use of maritime space, taking into account the relevant developments of sectoral policies as regards surveillance and contributing, as appropriate, to their necessary evolution" (EU Law, 2011: article 3) [ConPlaceful1].
}

Whereas, the EU's Marine Strategy is presented as "the environmental pillar of the IMP" (EU Law, 2011: preamble 12), the 2012 Commission's communication on the Blue Growth constitutes its economic pillar. The document is written in a way that rather represents the seas as placeless; mere "drivers of the economy", whose final cause is to create "jobs and growth" (Commission, 2012: 2). The seas must nonetheless be governed and controlled, since "the blue economy needs to be sustainable and to respect potential environmental concerns given the fragile nature of the marine environment. Efforts are needed to reduce negative environmental impacts of maritime activities" (Commission, 2012: 4) [ConPlaceless2]. But it also appears clearly that monitoring human activities and 'stewarding' the ocean is needed, even in an environment represented as placeless [ConPlaceful1]. Since the Blue Growth narrative rather constructs the sea as a placeless environment, it is not surprising that there is no geographical (let alone geopolitical) reference in this document, since the importance of the sea derives from what it eventually allows to achieve on land, i.e. economic growth and well-being, which echoes the concept of ecosystem services.

The 2014 MSS focuses on maritime security, but the overall goal of the EU is to contribute to promoting "better maritime governance" (Council, 2014: 8), for which the EU endorses responsibility for example by launching maritime capacity building missions (such as EUCAP Nestor at the Horn of Africa or EUBAM in Libya) focusing on coast-guard and maritime governance capabilities (ConPlaceful1, IgeoInfl2). Maritime zones in the periphery of Europe and beyond have a "strategic value" (Council, 2014: 4) to the EU [Tgeopol1, Tgeopol2 and DgeoInfl2]: "This Strategy takes particular regard of each of the European sea and subsea basins, namely the Baltic Sea, the Black Sea, the Mediterranean and the North Sea, as well as of the Arctic waters, the Atlantic Ocean and the outermost regions" (Council, 2014: 4). The Union has global strategic objectives that call for projecting security beyond the EU's jurisdictional waters. The MSS stresses the importance of contributing to the freedom of the sea and promoting good governance at sea. Whereas this corresponds to the traditional 'liberal' view adopted by the EU, power politics considerations are also at play [DgeoInfl1]: 


\begin{abstract}
"The Union stresses the importance of its assuming increased responsibilities as a global security provider, at the international level and in particular in its neighbourhood, thereby also enhancing its own security and its role as a strategic global actor" (Council, 2014: 8).

“Member States' Armed Forces should play a strategic role at sea and from the sea and provide global reach, flexibility and access that enable the EU and its Member States to contribute to the full spectrum of maritime responsibilities" (Council, 2014: 10).
\end{abstract}

This shows the extent to which the MSS is informed by geopolitical considerations that indirectly and directly impact on the recommended policies. There is some form of an inside versus outside narrative putting the emphasis on incoming threats and the need to monitor human activities at sea (maritime security, maritime surveillance), i.e. a narrative that promotes the projection of the legitimate use of violence into the maritime domain so as to overcome its unregulated status [Conplaceless1]. This maritime security narrative echoes the above-discussed ocean governance narrative. Security, economic and environmental threats, as well as the response to those threats, are presented in an interrelated manner, with several references to the IMP and the Blue Growth agenda.

Table 2: Summary of the qualitative content analysis of four EU maritime-related documents

\begin{tabular}{|c|c|c|c|c|c|c|c|c|c|c|c|c|}
\hline & \multicolumn{4}{|c|}{$\begin{array}{l}\text { Need for ocean } \\
\text { governance and control }\end{array}$} & \multicolumn{4}{|c|}{$\begin{array}{l}\text { Geopolitical approach to } \\
\text { ocean governance }\end{array}$} & \multicolumn{4}{|c|}{$\begin{array}{c}\text { Policy objectives } \\
\text { informed by geopolitical } \\
\text { considerations }\end{array}$} \\
\hline & \multicolumn{2}{|c|}{ Placeful } & \multicolumn{2}{|c|}{ Placeless } & \multicolumn{2}{|c|}{ Tacit } & \multicolumn{2}{|c|}{ Explicit } & \multicolumn{2}{|c|}{ Indirect } & \multicolumn{2}{|c|}{ Direct } \\
\hline & \multicolumn{2}{|c|}{ Conplaceful } & \multicolumn{2}{|c|}{ Conplaceless } & \multicolumn{2}{|c|}{ Tgeopol } & \multicolumn{2}{|c|}{ Egeopol } & \multicolumn{2}{|c|}{ IgeoInfl } & \multicolumn{2}{|c|}{ DgeoInfl } \\
\hline & 1 & 2 & 1 & 2 & 1 & 2 & 1 & 2 & 1 & 2 & 1 & 2 \\
\hline Marine Strategy & $\checkmark$ & & $\checkmark$ & & 2 & $\sqrt{ }$ & & $\sqrt{ }$ & $\sqrt{ }$ & & & $\checkmark$ \\
\hline $\begin{array}{l}\text { Integrated } \\
\text { Maritime Policy }\end{array}$ & $\bar{\checkmark}$ & & $\checkmark$ & & & & $\checkmark$ & $\sqrt{ }$ & & & & $\checkmark$ \\
\hline Blue Growth & $\sqrt{ }$ & & $\sqrt{ }$ & & & & & & & & & \\
\hline $\begin{array}{l}\text { Maritime Security } \\
\text { Strategy }\end{array}$ & $\checkmark$ & & $\checkmark$ & & $\checkmark$ & $\checkmark$ & & & & $\checkmark$ & $\checkmark$ & $\checkmark$ \\
\hline
\end{tabular}

As summarised in Table 2, in the four documents, ocean governance and maritime security are presented as responding to both the challenges posed by human activities in the maritime domain (placeful) and the issues posed by a placeless, lawless environment. The characteristics of the milieu are described as posing issues (e.g. 'fish cross borders') but the social importance of the sea is acknowledged as well. The geopolitical approach to ocean governance and maritime security is tacitly and/or explicitly present in three texts as is the direct and/or indirect influence of geography and/or geopolitics on maritime policy objectives, with indicators found throughout the three texts. In the case of the Blue Growth narrative, the lack of geographical and geopolitical references is explained by the placeless framing of the narrative.

In sum, the EU's ocean governance and maritime security narrative emphases the need to govern, steward and control the sea across various dimensions, i.e. marine environment and resources protection, regulating human activities at sea, and securing the maritime domain. The ultimate goal is to contribute to economic growth and well-being (on land), but in 
practice it requires projecting the EU's power and norms into the maritime domain, which will be discussed in the next section.

\subsection{The EU's practice of ocean governance and maritime security}

In practice, the EU has been active at sea across dimensions and in various adjacent and more remote areas, with both naval operations (counter-piracy, maritime capacity-building, and counter-human smuggling), as well as beyond the CSDP, with fisheries protection, marine environment protection norms, ocean surveillance, counter-immigration, etc. In addition to the narrative, the practice shows that security is somewhat at the centre of the EU's ocean governance efforts: hard security on the one hand (with naval and police operations, maritime surveillance, port security norms, etc.), economic and environmental security on the other hand. In other words, the EU is a comprehensive maritime actor with a particular interest in securing the seas.

As shown in table 3, the EU benefits from a range of instruments that offer a comprehensive leverage. It is beyond the scope of this article to assess the success of the EU's various policies and operations in the maritime domain. However, it is important to stress that this practice corresponds to (normative) power projection at sea and to a certain territorialisation of the sea, especially in the maritime margins of the Union, notably the Wider Mediterranean, from the coasts of Senegal to the Horn of Africa, but also the Black Sea, the Baltic Sea, the Atlantic ocean, and the Arctic ocean. From one area to the other, the degree of control the EU exercises at sea varies from high and multidimensional (environment, economy, security) in the wider Mediterranean to low and unidimensional (especially marine resources protection) in the Arctic. 
Table 3: The EU's ocean governance and maritime security practice (indicators)

\begin{tabular}{|c|c|c|}
\hline $\begin{array}{l}\text { Instruments } \\
\text { (non-exhaustive) }\end{array}$ & $\begin{array}{l}\text { Activities } \\
\text { (some examples) }\end{array}$ & $\begin{array}{l}\text { Main spatial } \\
\text { locations }\end{array}$ \\
\hline CSDP & $\begin{array}{l}\text { - EUNAVFOR-HoA (counter-piracy) } \\
\text { - EUNAVFOR-Med (counter-human smuggling) } \\
\text { - EUCAP Nestor (maritime capacity building) }\end{array}$ & $\begin{array}{l}\text { - Horn of Africa } \\
\text { - Mediterranean Sea } \\
\text { - Horn of Africa }\end{array}$ \\
\hline $\begin{array}{l}\text { Instrument for } \\
\text { Stability }\end{array}$ & $\begin{array}{l}\text { - Critical Maritime Routes programme } \\
\text { (information sharing, capacity-building) }\end{array}$ & $\begin{array}{l}\text { - Gulf of Guinea, Indian } \\
\text { Ocean, South-East Asia }\end{array}$ \\
\hline Frontex Agency & $\begin{array}{l}\text { - Frontex operations } \\
\text { (coordination of member states' assets and } \\
\text { activities in counter-immigration and SAR) }\end{array}$ & $\begin{array}{l}\text { - Wider Mediterranean, } \\
\text { Baltic Sea, Black Sea }\end{array}$ \\
\hline $\begin{array}{l}\text { Common Information } \\
\text { Sharing Environment } \\
\text { (CISE) }\end{array}$ & - Maritime surveillance & $\begin{array}{l}\text {-Waters under member } \\
\text { states' sovereignty and } \\
\text { jurisdiction }\end{array}$ \\
\hline $\begin{array}{l}\text { European Maritime } \\
\text { Safety Agency } \\
\text { (EMSA), European } \\
\text { Fisheries Control } \\
\text { Agency (EFCA) }\end{array}$ & $\begin{array}{l}\text { - Maritime safety, Fisheries monitoring } \\
\text { (harmonising norms, coordinating member stat } \\
\text { for control and repression) }\end{array}$ & $\begin{array}{l}\text { - Waters under member } \\
\text { states' sovereignty and } \\
\text { jurisdiction }\end{array}$ \\
\hline EU Law & $\begin{array}{l}\text { - Norms and regulations (binding) in the field of } \\
\text { maritime transport, fisheries, marine } \\
\text { environment protection, port security, etc. }\end{array}$ & $\begin{array}{l}\text { - Waters and territories } \\
\text { under member states' } \\
\text { sovereignty and } \\
\text { jurisdiction }\end{array}$ \\
\hline
\end{tabular}

The geographical aspect of the EU's practice is crucial, since ocean governance is a question of controlling spaces. But what about the nature of this maritime space: does the EU operate in a placeless or a placeful environment? As already noticed in the previous sections, ocean governance is a form of control over maritime spaces but also a form of control over human activities in the maritime domain. The ultimate goal and actual effect of the EU's policies and activities at sea is the growth of the EU's economy and, downstream, the well-being of EU citizen on land, which corresponds to a representation of the oceans as placeless. The importance of the sea for the EU is mainly reduced to land considerations. However, the practice of control and governance at sea rather corresponds to a territorialisation of the sea, and thus to a placeful representation of the oceans, which are constructed not as the land's other but as a different sort of place that nonetheless must be controlled and governed since it is the theatre of human, social and political interactions, including detrimental ones that need to be governed, managed, and eventually repressed.

\section{Conclusion: The Sea is a Place}

Quoting Mary Oliver's verse, Steinberg concludes his Social Construction of the Ocean by stressing that the "the sea isn't a place..." (2001: 206). This article has shown that the sea constitutes a place, at least to some extent. The case of the EU illustrates the extent to which public power (in this case the EU) has extended its control over the maritime domain. Ocean governance and maritime security translate into a practice consisting in controlling the maritime space leading to a certain territorialisation of the sea, not so much from a 
sovereignty and jurisdictional perspective but from a functional and normative perspective, with the EU's governing role being extended to the maritime domain. The narrative justifying such a practice emphasises both the need to control the maritime domain so as to maintain the freedom of the seas and the need to control the sea just as the land is controlled; to contribute to security and well-being. Whereas previous studies on the EU's maritime policies have been unidimensional, focusing either on security or on environment/resources protection, this article has shown that the EU aims at comprehensively exercising control over the maritime domain, at all levels.

The article has also demonstrated that the sea must be tackled as a placeful environment, so as to grasp the complex reality of ocean governance and maritime security in the $21^{\text {st }}$ century. The practice responding to the need to control human activities at sea illustrates the extent to which the oceans are the theatre of human, social and political interactions. However, the narrative is more balanced: on the one hand the sea is represented as a 'normal' place that must 'naturally' be controlled; a mirror of the situation on land (placefulness). On the other hand, the need to control the sea is also presented as a response to the issues (such as criminality) resulting from the intrinsic characteristics of the sea, i.e. a lawless and 'empty' space (placelessness).

A recent renewed academic interest for the sea has been noted. Connery speaks of a "scholarly turn to the ocean" (2006: 496). For Spence (2014: 203), researchers should now investigate the "how" to study the sea, and not so much the "why" anymore, and she proposes to develop a "more-than-sea Geography", which consists in conceptualising "the host of relations that transcend wet-dry, human-non-human, surface-air binaries that originate from and are specific to the sea". The disciplinary boundaries within social science have resulted in various scholars tackling the representation of the sea and/or the issues of control and ocean governance in a rather fragmented way, such as critical geography (see Steinberg, 2001), literature (see Connery, 2006), sociology (see Glück, 2015), international relations (see Germond, 2013; 2015b), and art (see Cuzack, 2014). Across academic boundaries, this article encourages scholars working on ocean governance, maritime security and the representation of the oceans to critically tackle the traditional view that oceans are placeless and consider them as a placeful environment.

\section{References}

J. Anderson and K. Peters (2014), “'A perfect and absolute blank': Human Geographies of Water Worlds", in J. Anderson \& K. Peters (eds), Water Worlds: the Human Geography of the Oceans, Ashgate, Farnham, pp.3-19.

A. Baldaccini (2010), "Extraterritorial Border Controls in the EU: The Role of Frontex in Operations at Sea", in B. Ryan and V.Mitsilegas (eds), Extraterritorial Immigration Control, Martinus Nijhoff Publishers, Leiden and Boston, pp.229-257.

I. Brstilo (2013), "Filipino Seafarers as Seabased Global Diaspora. Contribution to Maritime Sociology”, Annuals of Marine Sociology (Roczniki Socjologii Morskiej), Vol.XXII, pp.2737.

C. Bueger (2013), “The global fight against piracy”, Global Policy, Vol.4, No.1, pp.63-64.

C. Bueger (2014), "Piracy studies: academic responses to the return of an ancient menace", Cooperation and Conflict, Vol.49, No.3, pp.406-416. 
C. Bueger (2015), "Learning from piracy: lessons for maritime security governance", Global Affairs, Vol.1, No.1, pp.33-42.

B. Buzan, O. Weaver and J. de Wilde (1998), Security: A New Framework for Analysis, Lynne Rienner, Boulder and London.

S.R. Bush and A.P.J. Mol (2015), "Governing in a placeless environment: sustainability and fish aggregating devices, Environmental Science \& Policy, Vol.53, Part A, pp.27-37.

Commission of the European Communities (2007), An Integrated Maritime Policy for the European Union, COM(2007) 575 final, Brussels.

Commission of the European Communities (2012), Communication from the Commission to the European Parliament, the Council, the European Economic and Social Committee and the Committee of the Regions: Blue Growth: opportunities for marine and maritime sustainable growth, $\operatorname{COM}(2012) 494$ final, Brussels.

J. Corbett (1911), Some Principles of Maritime Strategy, United States Naval Institute, Annapolis, 1988, first published by Longmans, London, 1911.

C.L. Connery (1994), "Pacific Rim Discourse: The U. S. Global Imaginary in the Late Cold War Years", boundary 2, Vol.21, No.1, pp.30-56.

C.L. Connery (2006), "There was No More Sea: the supersession of the ocean, from the bible to cyberspace", Journal of Historical Geography, Vol.32, No.3, pp.494-511.

Council of the European Union (2003), A Secure Europe in a Better World: European Security Strategy, Brussels.

Council of the European Union (2014), European Union Maritime Security Strategy, 11205/14, Brussels.

T. Cuzack (2014), "Introduction: Framing the ocean, 1700 to the present: envisaging the sea as social space", in T. Cuzack (ed), Framing the Ocean, 1700 to the Present, Envisaging the Sea as Social Space, Ashgate, Farnham, pp.1-22.

Maria Damanaki (2014), "European Maritime Security Strategy: Moving Forward", Speech at the CHENS (CHiefs of European NavieS) annual meeting, Portsmouth, 23 May 2014, available at http://europa.eu/rapid/press-release_SPEECH-14-408_en.htm

EU law (2008), Directive 2008/56/EC of the European Parliament and of the Council of 17 June 2008 establishing a framework for community action in the field of marine environmental policy (Marine Strategy Framework Directive), Official Journal of the European Union, 25.6.2008, L 164/19-L 164/40.

EU law (2011), Regulation (EU) No 1255/2011 of the European Parliament and of the Council of 30 November 2011 establishing a Programme to support the further development 
of an Integrated Maritime Policy, Official Journal of the European Union, Volume 54, 5 December 2011, L 321/1-L 321/10.

B. Germond (2007), "The Naval and Maritime Dimension of the European Union", in G. Bossuat and A. Deighton (eds), The EC/EU: a world security actor?, Soleb, Paris, pp.346361.

B. Germond (2010), "From Frontier to Boundary and Back Again: The European Union's Maritime Margins”, European Foreign Affairs Review, Vol.15, No.1, pp.39-55.

B. Germond (2011), "The EU's security and the sea: defining a maritime security strategy", European Security, Vol.20, No.4, pp.563-584.

B. Germond (2013), "The European Union at the Horn of Africa: Contribution of Critical Geopolitics to Piracy Studies", Global Policy, Vol.4, No.1, pp.80-85.

B. Germond (2015a), "The Geopolitical Dimension of Maritime Security", Marine Policy, Vol.54, April 2015, pp.137-142.

B. Germond (2015b), The Maritime Dimension of European Security: Seapower and the European Union, Palgrave Macmillan, London and New York.

B. Germond and M.E. Smith (2009), "Re-thinking European security interests and the ESDP: Explaining the EU's anti-piracy operation", Contemporary Security Policy, Vol.30, No.3, pp.573-593.

C. Germond-Duret (forthcoming), "Tradition and Modernity: An Obsolete Dichotomy? Reflexion on Binary Thinking and Indigenous Peoples", Third World Quarterly.

Z. Glück (2015), "Piracy and the production of security space", Environment and Planning D: Society and Space, Vol.33, online.

J.R. Gillis (2011), "Filling the Blue Hole in Environmental History", in K. Coulter and C. Mauch (edds), The Future of Environmental History Needs and Opportunities, Rachel Carson Center for Environment and Society, Munich, pp.16-18.

J.R. Gillis (2012), The Human Shore, The University of Chicago Press, Chicago.

L. Gui and A.P. Russo (2011), "Cruise ports: a strategic nexus between regions and global lines - evidence from the Mediterranean", Maritime Policy \& Management: The flagship journal of international shipping and port research, Vol.38, No.2, pp.129-150.

D. Lambert, L. Martins and M. Ogborn (2006), "Currents, visions and voyages: Historical geographies of the sea", Journal of Historical Geography, Vol.32, No.3, pp.479-93.

J.S. Lehman (2013), "Relating to the sea: enlivening the ocean as an actor in Eastern Sri Lanka", Environment and Planning D: Society and Space, Vol.31, No.3, pp.485-501.

P. Papa (2013), "US and EU strategies for maritime transport security: A comparative perspective", Transport Policy, Vol.28, No.C, pp.75-85. 
E. Papastavridis (2010), "Fortress Europe and FRONTEX: Within or without International Law", Nordic Journal of International Law, Vol.79, No.1, pp.75-111.

E. Relph (1976), Place and Placelessness, Pion Limited, London.

M. Riddervold (2011), "Finally flexing its muscles? Atalanta - The European Union's naval military operation against piracy", European Security, Vol.20, No.3, pp.385-404.

M. Riddervold (2014), "New threats - different response: EU and NATO and Somali piracy", European Security, Vol.23, No.4, pp.546-564.

E. Spence (2014), "Towards a more-than-sea geography: exploring the relational geographies of superrich mobility between sea, superyacht and shore in the Cote d'Azur", Area, Vol.46, No.2, pp.203-209.

P.H. Steinberg (2001), The Social Construction of the Ocean, Cambridge University Press, Cambridge.

J.L. Suárez de Vivero and J.C. Rodríguez Mateos (2006), "Maritime Europe and EU enlargement. A geopolitical perspective", Marine Policy, Vol.30, No.2, pp.167-172.

J.L. Suárez de Vivero, and J.C. Rodríguez Mateos (2010), "Ocean governance in a competitive world. The BRIC countries as emerging maritime powers - building new geopolitical scenarios", Marine Policy, Vol.34, No.5, pp.967-978.

G. Ó Tuathail J.and Agnew (1992), "Geopolitics and discourse: practical geopolitical reasoning in American foreign policy", Political Geography, Vol.11, No.2, pp.190-204.

G. Ó Tuathail (1996), Critical Geopolitics, Routledge, London.

M. Tyrrell (2006), "From Placelessness to Place: An Ethnographer's Experience of Growing to Know Places at Sea", Worldviews: Global Religions, Culture, and Ecology, Vol.10, No.2, pp.220-238. 